\title{
SELF-NARRATIVES OF BRAZILIAN DEAF PEOPLE: APPLICATION OF THE HYPOTHESES OF SOCIOANALYSES
}

\author{
CLEIDE EMILIA FAYE PEDROSA ${ }^{1}$ \\ ${ }^{1}$ Federal University of Sergipe, Av. Marechal Rondon, s/n - Jardim Rosa Elze, São Cristóvão - SE, 49100- \\ 000, Brazil. ORCID: 0000-0003-4021-8189, Email: cleidepedrosa@oi.com.br
}

\begin{abstract}
The objective of this study is to apply eight hypotheses of the socioanalysis for the interpretation and critical social reading of the "self-narratives" of deaf candidate to Higher Education at the Federal University of Sergipe (UFS-Brazil). It is in the theoretical-methodological field of Critical Discourse Analysis (CDA), and Deaf Studies (DS). We will analyze a deaf subject's narrative, collected in 2014, in the college entrance examination for the Brazilian Sign Language Course (LIBRAS). We will also adopt this methodological guideline, to define the object of study; identify areas of interfaces that meet the objectives; select the categories of each area of interface; establish the dialogue between categories, and identify the social meanings constructed in the discourse. The result confirms the role of socioanalysis in seeking to unveil how the practice of social relations and (re)construction of their identities in the struggle for citizenship rights articulate in the deaf individual's life. KEYWORDS: Hypotheses of socioanalysis; Self-narratives; Higher education; Deaf Studies; Critical Discourse Analysis
\end{abstract}

\section{INTRODUCTION}

Studies on the construction of narratives, such as self-interpretation, have grown in various fields, such as Sociology (for Social Change), Applied Linguistics (AL), and 
Deaf Studies (DS). Ricoeur (2013) says that the individual can constitute their identity in narrating themselves - what he calls "narrative identity".

To this purpose, the Sociological and Communicational Approach to Discourse (SCAD), a Brazilian approach that is part of the field of Critical Discourse Analysis (CDA), recontextualizes the hypotheses of socioanalysis, from the field of Sociology for Social Change (SSC) and applies them to the self-narratives of vulnerable groups.

Therefore, the objective of this work is to apply the eight hypotheses of the socioanalysis for the interpretation and critical social reading of the "self-narratives" of deaf candidates to Higher Education at the "Universidade Federal de Sergipe" (UFS), Brazil. In order to fulfill this objective, it will be developed from the theorization of the fields in dialogues, which are: Critical Discourse Analysis (CDA); Sociological and Communicational Approach to Discourse (SCAD) and Deaf Studies (DS). From the CDA, we will highlight its political commitment to make explicit the vulnerability of minority groups and the abuse of power relations that are imposed on them. From the SSC, we will summarize the proposal of the eight hypotheses of the socioanalysis and its contribution to the studies self-narratives. From the DS, we will summarize the history of the attempts to apply a methodology for the education of deaf people.

\section{“SELF-NARRATIVES” OF DEAF PEOPLE: THE THEORETICAL PERSPECTIVES OF CRITICAL DISCOURSE ANALYSIS AND SOCIOLOGY FOR SOCIAL CHANGE}

From Linguistics, we situate CDA (Fairclough 2008; Pedrosa 2008; Magalhães, Martins and Resende 2017). This field of linguistic-discursive analysis of social issues have evidenced its role in an incisive way. Their ability to being critical "springs from their dialogue with critical social science”, as Vieira and Macedo (2018: 62) state. The authors continue to point out the questioning that this theory makes about the political and moral aspects of life in society.

For CDA, the role of the subject, or social actors, is crucial in the changes of discursive and social practices, evidenced in all texts, the similarity of the self-narratives that we are going to study. Thus, the analysis of texts is not only linguistic, but an "analysis of texts in terms of the different discourses, the different genres and the different styles they articulate" (Vieira and Macedo 2018: 62).

The objectives of CDA are aligned with this analytical positioning of texts and reflective of worldview. To explain the focus of CDA, we will summarize them in their fundamental objective, following Gonçalves-Segundo:

A critical approach to discourse - and broader social life - must take into account the structural constraints of the various practices in which we are involved, while valuing our capacity to act and, above all, to reflect and to resist, so that we can glimpse the fundamental objective: the denunciation of relations of power and domination that oppress and exclude in order to try to make a more egalitarian, just and democratic society (Gonçalves-Segundo 2018: 79).

"The denunciation of relations of power and domination that oppress and exclude", as the practice of critical analysts, it is the crucial point, to "enable a more just, more 
egalitarian society”, including for the deaf people, as a linguistic minority that has suffered throughout the history of humanity.

According to several authors from the deaf community, the deaf people bring in their body and in their memory marks of atrocities, because social coexistence was denied to them in several phases of history. This denial can range from isolation to death (Strobel 2009).

Europe, and other continents, were also in the competition of methods for schooling the deaf. In two extremes, there is oralism, in 1755, with Samuel Heinicke, known as the father of the German method, and the signage with the French abbot Charles Michel de L'Epée (1712-1789). The importance of these representatives of deaf education is so remarkable that Heinicke, in 1978, receives a postage stamp in his honor. The abbot, creator of methodical signs and also the creator of the first school for the deaf in France, also receives a postage stamp in his honor in 1959 (Sofiato and Reily 2017).

Poland, where this research was presented ${ }^{1}$, is a country that, on one hand, has a long tradition in education for the deaf and has suffered a great deal of historical turbulence that has had a direct impact on this model of education. According to Tomaszewski and Sak (2014: 131), in the first school for the deaf in Poland - the Institute for the Deaf, dated 1817, the manual method was adopted. This method was discontinued between the $19^{\text {th }}$ and $20^{\text {th }}$ centuries due to the implementation of rehabilitating ideologies. "This was the organization of the educational process involving the 'normalization' of deafness that was almost openly highlighted". In the authors' evaluation, "in fact, it was nothing more than education aimed at adapting the deaf to the majority of hearing people".

In altercations between orality and signalization, in 1880 (06-11 September), in the Milan Congress, oralism was defined as the best method for the education for the deaf. This decision made by the hearing experts in the education for deaf people had very little influence on this resolution. As Rochelle (1880) informs us, the main deliberations were for the oral method. The thesis was that the voice should precede writing. Let us see:

(...) however, despite some resistance, the method of articulation prevails visibly. Its triumph is affirmed in a resolution formulated: Congress, Considering the undoubted superiority of the word on the signs to deaf-mute society and give it a more perfect knowledge of the language, states that the oral method should be preferred instead of mimicry for the education and instruction of the deaf-mute (Rochelle 1880: 10, our translation).

These decisions reached deaf education in several parts of the world, such as Brazil, which, in 1881, educators prohibited the use of sign language at its Institute of the Deaf-Mute (Rocha 2008).

\footnotetext{
${ }^{1}$ International Conference Language and Society. Research Advances in Social Sciences Maria Grzegorzewska University Warsaw, Poland, September 26-27, 2019.
} 
As Eiji (2012) says, in the face of the strength of the narrative plots of the hearing people's ideology and circulation of the pathological discourses about deafness, the siege for the method of oralism was closed. "From deaf people were demanded with speaking, orofacial reading, hearing training, the elimination of gestures, hearing people's behaviors, rehabilitation efforts and isolation concerning deaf communities" (Eiji 2012)2. It was the quest to "normalize" the deaf.

As it was aforementioned, this work has as object of study deaf people's self-narratives. Specifically, we will work with a narrative through the theoretical and methodological basis of the Sociological and Communicational Approach to Discourse (SCAD, ASCD in Portuguese, www.ascd.com.br) (Pedrosa 2016, 2018), a Brazilian approach within CDA. The SCAD was idealized through contextualization and contributions from several areas, such as Sociology for Social Change (SSC); Communication for Social Change (CSC); Cultural Studies (CS) and Systemic-Functional Linguistics (SFL).

In order to work on self-narratives, we chose the influence of the SSC, through its exponent, the sociologist Bajoit (2006, 2008, 2009, 2012, 2013). According to him, the individual, in order to be subject, exercises the psychic resources of one's own consciousness, i.e., one's own capacity for reflexivity and expressiveness. The individual can also be questioned by one's own culture in order to be subject or to be an actor. However, we know that this is not always the case, especially when we speak of vulnerable groups or minorities.

The sociologist indicates two types of self-narratives (expressivity): of understanding and relief. The narratives of understanding can be of rationalization and of conscientization. The rationalization explains the reason why the subject is under the conditions described in the narrative. It can be because of his/her parents, teachers, human nature, fatalities, God, and other causes. In the narratives of conscientization, the subject reflects how he/she acts independently on his/her will, the habits he/she has incorporated, Freudian slips, etc.

Narratives of relief are classified as evaluation, withdrawal, compensation, and perseverance. The narrative of evaluation analyses the gravity of what happened to him/ her as a victim, sometimes as guilty, sometimes minimizing or exaggerating the situation. The narrative of withdrawal considers only a postponement, or the act of being far from his/her mourning because of his/her failure. The narrative of compensation tries to replace a frustration to an expectation (substitution or sublimation). The last one is of perseverance, which evaluates the possibility of reconciling him/herself to the situation or change his/her life (Bajoit 2012).

The self-narrative to be analyzed will be interpreted according to the classification above and to the socioanalysis hypotheses that will be explained in the methodological section below.

\section{METHODOLOGY}

The objective of this study is to apply eight hypotheses of the socioanalysis for the interpretation and critical social reading of the "self-narratives" of deaf candidate to

\footnotetext{
${ }^{2}$ https://culturasurda.net/2012/08/18/teatr-deaf-poland/, 05/05/19, at 00:59).
} 
Higher Education at the Federal University of Sergipe (UFS-Brazil).

We will analyze a self-narrative of a deaf subject, from a corpus collected in $2014^{3}$. The narrative in evidence was the textual production for the selection test to enter the graduation in LIBRAS (Brazilian Sign Language). The candidate, who wrote an essay-argumentative text defending bilingual education for deaf people, uses his/her own life story to support the arguments. Thus, the self-narrative, "embedded" in the text on the agenda, occupies much of the production.

We adopted the basic methodological guidelines in the SCAD, for a qualitative and interpretative study, as follows:

- To identify the areas of interfaces that meet the objectives - CDA, Sociological and Speech Communication Approach, DS, SFL.

- To select the categories of each interface area - the hypotheses of socioanalysis, types of narratives, metafunctions of the SFL.

- To articulate discursiveness to its textual materiality - indicate the textual texture by the metafunctions of the SFL and the self-narrative.

- To establish a dialogue between the categories - establishment of the type of narrative and the hypotheses; to identify the social meanings represented and constructed in the corpus - the social meanings from the methodologies for deaf teaching.

From Socioanalysis, derived from SSC, and recontextualized and applied by SCAD, we have the following literal assumptions of Bajoit (2012):

First hypothesis: the practice of social relations, by socializing the individual, instigates him/her to engage in a social destiny.

Second hypothesis: engagement in a social destiny awakened in the individual of relational expectations: some are well satisfied, others are less satisfied or are not at all.

Third hypothesis: relational expectations that are satisfied form the central core of personal identity; those who are not satisfied, feed existential tensions in the peripheral zones of that identity.

Fourth hypothesis: certain conditions weaken the identity of the individual and produce identity uneasiness that instigates him/her to question the destiny in which he/ she is engaged.

Fifth hypothesis: the individual constructs a narrative of the subject, by which he/she explains to him/herself his/her identity uneasiness and projects what he/she wants to

\footnotetext{
${ }^{3}$ Some smaller projects started in 2013 at the Federal University of Rio Grande do Norte (Brazil) and currently at the Federal University of Sergipe - UFS, (Brazil). Specifically, the text, for analysis, is part of the corpus of the project "Studies of identities and writing processes in Portuguese as L2: deaf community in agenda" (registration code at UFS - pvd5106-2017). We collected 54 essays referring to the selection of deaf candidates of 2014 (25 essays), 2015 (08 essays), 2016 (15 essays), and 2017 (6 essays). In the latter, the project to be developed from 2019 to 2024, was submitted to the UFS Ethics and Research Council and has the title: "Critical discourse analysis and vulnerable groups: self-narratives and the identity constructions of the deaf subject".
} 
do to relieve it.

Sixth hypothesis: the individual constructs the subject's reasons: his/her motivations to move to the act and the resistances that oppose him/her.

Seventh hypothesis: the individual implements the psychic abilities that weaken his/ her internal resistances and allow him/her to perform liberating acts.

Eighth hypothesis: the individual moves into action: he/she somewhat profoundly redefines his/her social relations... and he/she pays the price of his/her always partial liberation!

These hypotheses, applied by Bajoit in basic research in Sociology for Social Change, will be retextualized to accompany the critical reading of the deaf's self-narrative. We justify their use because we could not find any research that applies them to socio-discursive studies in CDA and in DS.

For textual weaving, Systemic-Functional Linguistics (SFL) will be the basis. The focus will be the general aspects of meta-functions: ideational and interpersonal. By ideational function, we analyze the worldview in a text; by interpersonal function, we follow the dialogism in the text.

The following topics, results and discussion, will, respectively, focus on critical reading from the hypotheses and Systemic-Functional Linguistics.

\section{RESULTS}

Ricoeur (2013: 02) explains that "self-knowledge is an interpretation". According to the author, knowing oneself happens indirectly "by the diversion of cultural signs of all sorts that are articulated on symbolic mediations, which, in turn, articulate action and, among them, the narratives of daily life". It is this interposition by the narrative that promotes "self-knowledge" as "an interpretation of oneself” (Ricoeur 2013: 13, 14).

Below there is an example of analysis, i.e., a narrative that a subject built to explain his/her existential tensions.

Example:

Applicant: LL-UFS/2014

\footnotetext{
${ }^{4}$ Entendo que a escola bilíngue é a melhor forma de inserir os surdos na educação escolar brasileira. E faço, defendo essa posição com base em minha própria experiência como estudante.

Eu nasci surdo e, por força do pensamento fonoaudiológico então vigente, fui rigirosamente oralizado, sendo-me negado qualquer contato com a língua de sinais.

Aos 7 anos, comecei a estudar em escola particular, lá estudando até entrar na [nome de uma universidade pública]. Para mim, foi um choque quando entrei na Universidade, pois esta não tinha preparação alguma para acolher o surdo, o mesmo se dando na [nome de uma universidade particular], quando entrei lá posteriormente

Hoje, não me sinto bem exercendo o papel de ouvinte (o que, decididamente, não sou) nem consigo ficar à vontade entre os meus iguais, pois não domino a LIBRAS, que só vim a descobrir muito tarde, com 35 anos de idade.

Assim, com a atual onda de valorização da LIBRAS, que se tornou a $2^{\text {a }}$ língua oficial do Brasil, é mister que se busque, igualmente, a valorização do surdo em sua integralidade, reconhecendo que a sua $1^{\mathrm{a}}$ língua é a LIBRAS, não o português, que é a $1^{\text {a }}$ língua do ouvinte.
} 
I understand that the bilingual school is the best way to insert the deaf in Brazilian school education. And I defend this position based on my own experience as a student.

I was born deaf and, because of speech therapy, I was strictly oralized, and I was denied any contact with the Brazilian sign language.

At age 7, I started studying in private school until I was admitted at [name of a Brazilian public university]. For me, it was a shock when I entered the university because there was no preparation to welcome the deaf. The same happened at [name of a Brazilian private university] when I went there later.

Nowadays, I do not feel good playing the role of a hearing person (which I am not, definitely) nor can I be comfortable among my equals, because I do not command LIBRAS, which I came to discover very late, at 35 years old.

Therefore, with the current wave of LIBRAS appreciation, which has become the $2^{\text {nd }}$ official language of Brazil, it is necessary to equally seek the appreciation of deaf people in their entirety, recognizing that their first language is LIBRAS, not Portuguese, which is the first language for hearing people.

If LIBRAS is treated as Portuguese, as an official Brazilian language, why not allow the creation of bilingual schools, which would make deaf people fully developed, instead of just inserting them in traditional monolingual schools, which will never give them conditions to their complete development, but, on the contrary, they could traumatize them, making them believe that Portuguese is a "boring" and "difficult" language to learn?

So, may the bilingual school be created.

In the text above, we marked in italics the paragraphs that constitute the self-narrative, which will be the object of analysis. We will also cut it into passages. To read the code (LL-UFS/2014), we have: graduation in LIBRAS (Brazilian Sign Language Course) from the UFS (Universidade Federal de Sergipe), in 2014.

\section{Passage 1:}

I was born deaf and, because of speech therapy, I was strictly oralized, and I was denied any contact with the Brazilian sign language.

\footnotetext{
Ora, se a LIBRAS está equiparada ao português como língua oficial brasileira, por quê não se admitir a criação de escolas bilíngues, que permitirão o desenvolvimento integral do surdo, em vez de apenas inseri-lo nas escolas nos moldes atuais, que jamais lhe darão condições de seu desenvolvimento pleno, mas, ao contrário, poderão traumatiza-lo, fazendo-o crer que o português é uma língua "chata" e "difícil" demais de aprender?
}

Assim, que venha a escola bilíngue!! 
I associate the passage 1 with the first hypothesis: "the practice of social relations, by socializing the individual, instigates him/her to engage in a social destiny". According to the sociologist Bajoit (2012), the use of the term "social destiny" in this hypothesis refers to when the subject does not choose his/her life's trajectory when he/she follows the route that was imposed or suggested to him/her. We verified that, in the case in study, his/her journey was imposed (I was strictly oralized, and I was denied any contact with Brazilian sign language). He/She was "strictly" forced to oralize by some external force, which he/she could not fight against. In this case, it was "because of speech therapy thought then in effect".

If we consider that the decision of the Milan Congress was in 1880, even after a century, the influence remains strong, since the person was born between the late 1970s and early 1980s, as he/she is 35 now.

Bajoit presents another reading for "social destiny": when the social actor chooses the destination. What is observed by the text is that the social actor continues, for a long time, engaged in the destiny that attributed to him/her.

Passage 2:

At age 7, I started studying in private school until I was admitted at [name of a Brazilian public university]. For me, it was a shock when I entered the university because there was no preparation to welcome the deaf. The same happened at [name of a Brazilain private university], when I went there later.

The subject, for many years, fulfills his/her social destiny hypothesis 2 - "engagement in a social destiny awakened in the individual of relational expectations: some are well satisfied, others are less satisfied or are not at all" (At age 7, I started studying in private school until I was admitted at [name of a Brazilian public university]). In hypothesis 3 ("relational expectations that are satisfied form the central core of personal identity; those who are not satisfied, feed existential tensions in the peripheral zones of that identity"), the subject's expectation of personal fulfillment failed. Whether entering a public or private university, his/her experience was not what he was expecting (For me, it was a shock when I entered the university because there was no preparation to welcome the deaf). The subjects have projects to do, and when they seek to accomplish them, they not always succeed. This is what happened in hypothesis 3 - "the [relational expectations] that are dissatisfied feed existential tensions in the peripheral zones of that identity".

According to socioanalysis, personal identities are inserted in three spheres that approach or distance themselves according to existential tensions that are solved or not. The sphere of the assigned identity - what the individual thinks he/she must do or be in order to respond to the expectations other people have for him/her; the sphere of the desired identity - what he/she expects to have to be and to do it in order to fulfill him/herself as a person; and the sphere of compromised identity - how he/ she manages to balance the other two spheres, that is, what he/she actually does with his/her life (Bajoit 2012). 
We verified, by the text, that the subject seeks to meet his/her desired identity, submitted to two exams to enter public and private universities, but the "shock" of disappointment was the same. His/her search for personal fulfillment was not achieved (For me, it was a shock when I entered the university because there was no preparation to welcome the deaf. The same happened at [name of a Brazilian private university] when I went there later).

By the fourth hypothesis ("certain conditions weaken the identity of the individual and produce identity uneasiness that instigates him/her to question the destiny in which he/she is engaged"), we realize that the subject only sought another university - a private one, because of the disappointment of entering the public university generated "identity uneasiness" that caused him/her to question his/her "social destiny". He/She would not conform to this situation, would seek another solution -the private university.

Passage 3:

Nowadays, I do not feel good playing the role of a hearing person (which I am not, definitely) nor can I be comfortable among my equals, because I do not command LIBRAS, which I came to discover very late, at 35 years old.

Through the Fifth Hypothesis ("the individual constructs a narrative of the subject, by which he/she explains to him/herself his/her identity uneasiness and projects what he/she wants to do to relieve it") we encounter the subject and "his/her self-narrative". We encounter his/her identity tensions, his/her decisions about the identity spheres (assigned, desired, or committed). It is this narrative that allows us to verify the other hypotheses.

We have identified that the subject's capacity for reflexivity and expressiveness is manifested in his/her text. It reflects on the lack of identification in the "hearing person's role" and in the deaf person's - I cannot even feel comfortable among my equals, because I do not command LIBRAS. This reflexivity also attests to his/her evaluation-type relief narrative. The subject evaluates the severity of his/her situation.

To close the other hypotheses, we must resort to the full narrative. In the sixth hypothesis ("the individual constructs the subject's reasons: his/her motivations to move to the act and the resistances that oppose him/her") and in the seventh hypothesis (the individual implements the psychic abilities that weaken his/her internal resistances and allow him/her to perform liberating acts), we find an explanation for the socio-discursive reading of the narrative. We can look for indications of their motivations and resistances. He/She faces selections that give him/her the opportunity to pursue a career. He/She resists and persists when the public university disappoints him/her and seeks a new selection for a private university.

According to Bajoit (2012: 24), we live under the domain of a subjectivist cultural model. This model gives the subject/actor at least "three major injunctions: it tells him/her 'to assert his/her rights, make his/her own choices and become him/herself'". Furthermore, the author adds: "he/she interprets these three injunctions in his/her 
way, according to his/her personal story, which will ground his/her reason and resistance". We find in the narrative under analysis that the subject is aware of his/her right to higher education and assesses it negatively when he/she finds universities without "any preparation to welcome the deaf" - For me, it was a shock when I entered the university because there was no preparation to welcome the deaf.

As this self-narrative was inserted in a text for selection to higher education, we can consider that the eighth hypothesis ("the individual moves into action: he/she somewhat deeply redefines his/her social relations... and he/she pays the price of his/her always partial liberation!") is linked to the act of redefining his/her social relations and resolving his/her existential tensions. When he/she did not get support in a university, he/she tries another one and again "pays" the price of not being accepted (Bajoit 2012). In the sociologist explanation:

To become the subject of oneself, the individual seeks to be more actor. In order to free oneself from one's resistances and to avoid the return of one's identity uneasiness, he/she strives to obtain a better satisfaction of his/her relational expectations and, to achieve it, he/she goes back to the source: he/she acts on the social relations that are in origin of the structure of one's own identity. With and/or against the "significant others" of his/her existence, he/she tries to redefine his/her aims, powers, social influence, and retributions: he/she enters into conflict, cuts off relations, builds solidarities, negotiates, imposes him/herself or give up (Bajoit 2012: 31).

The subject's dedication to his/her education was the way he/she "redefined his/her purposes, his competences". As the Brazilian educational system did not meet his/her linguistic priority, that is, to offer bilingual education, with Libras as the L1 and Brazilian Portuguese as the L2, he/she denounces this negligence. He/She explains that his/ her education was in written and "oralized" Brazilian Portuguese. Because of that, he/ she feels him/herself in a floating identity, i.e., neither hearing nor deaf, he/she stands in favor of bilingualism.

\section{DISCUSSION}

The textual analysis, necessary in research with CDA, will be added to the critical reading through the Systemic-Functional Grammar.

If we consider the metafunctions of the language in use (Halliday 2004; Ghio and Fernandes 2005), they point to a worldview based on hearing people's ideology, of normality (ideational metafunction, representational), from the position of the subject that does not feel comfortable neither with deaf people nor with hearing people. Consolidating, thus, the theory exposed by the authors Ghio \& Fernandes (2005: 79), when they affirm that "as a representation: the clause contradicts some process of the human experience of the world". Moreover, Halliday (2004) distinguishes two subfunctions in the ideational metafunction: experiential and logical. We are concerned here with the experiential subfunction, since through language human beings can construct mental images of the exterior and interior "reality", some of these images: 
I was strictly oralized; I started studying in private school; it was a shock when I entered the university; Nowadays, I do not feel good playing the role of a hearing person. His/Her experience is constituted by events that are accomplished in language by verbal processes.

Still, Ghio and Fernandes (2005: 79) explain, about interpersonal metafunction, that it "implies a transaction between speaker and hearing or audience". From this point of view, the language will serve both to establish and to maintain social relations. It will serve to realize our social roles. The subject's social relations in the narrative always occur with hearing people. His/Her assessment of this relationship is always negative, considering that he/she was forced into various hearing people's circumstances, despite being deaf. He/She was "strictly" oralized. He/She was "denied" any contact with his/her language. The university "had no preparation" at all. "I do not feel good" in the role of a hearing person.

According to Bajoit (2013), in order to be subject, the person must "build a narrative identity by which he/she explains and relieves his/her existential tensions, and he/she explains, justifies, evaluates, considers what he/she could do to solve his/her discomfort, thanks to a set of narrative processes". Furthermore, he/she adds: "He/She strives to adhere to this story, to repeat it relentlessly to convince him/herself of it, to believe that it guides his/her action".

$\mathrm{He} / \mathrm{she}$ used a self-narrative in his/her text to explain his/her existential tension, resulting mainly from his/her linguistic exclusion, denial to use his/her language, and to constitute his/her deaf identity.

\section{CONCLUSION}

The result confirms the role of socioanalysis, recontextualized by the Sociological and Communicational Approach to Discourse, in seeking to reveal how it is articulated in the deaf's life the practice of social relations and the (re)construction of their struggle identity for citizenship rights.

As Bajoit says, about the individual's ability to narrate his/her uneasiness, resulting from the social relationship to which he/she is subjected:

The two capacities of his/her consciousness, expressiveness and reflexivity, inspire the individual to have what he/she must do if he/she wants to be more subject of him/herself: they are the ones that instigate him/her to build a credible identity narrative to understand and relieve his/her uneasiness... to mobilize their energy to give themselves reason to act (Bajoit 2012: 27).

Critical Discourse Analysis, through its linguistic, discursive, and social basis, and in dialogue with critical social science, has contributed to the analysis of the discourses of vulnerable groups through their political view of social life, exposing the structural coercion of various practices to which these groups are submitted. Moreover, in this way, it aims to promote action as resistance to abusive power relations. As a result, it tries to "make possible a more egalitarian, fair, and democratic society" (Gonçalves-Segundo 2018: 79). 
In short, we can affirm that the narrative analyzed demonstrated how much the deaf subject, representative of other deaf people, suffered the imposition of a language and a culture that was not his/her own. We also affirm that we must make his/her last "cry", that he/she does not know who he/she is (Nowadays, I do not feel good playing the role of a hearing person (which I am not, definitely) nor can I be comfortable among my equals, because I do not command LIBRAS, which I came to discover very late, at 35 years old), be replaced by an identification with his/her people and language.

FUNDING: This research received no external funding.

CONFLICT OF INTEREST: The author declares no conflict of interest.

ACKNOWLEDGEMENTS: I would like to thank the Federal University of Sergipe-Brazil for granting me a paid license for postdoctoral studies at the University of Lisbon, Portugal (Ordinance No. 465 of April $\left.2^{\text {nd }}, 2019\right)$, the International Sector of the Faculty of Modern Languages for accepting me as a Visiting Researcher, and Professor Carlos Gouveia, Ph.D for accepting this research tutoring. The student Deborah Diniz, a CNPq scholarship holder (2016, 2017), for scanning and typing the text used for analysis. Also, Tamires Cruz for the translation to English.

\section{REFERENCES}

Bajoit, Guy. 2006. Tudo muda: proposta teórica e análise da mudança sociocultural nas sociedades ocidentais contemporáneas. Ed. Unijuí: RS, Brasil.

Bajoit, Guy. 2008. El cambio social, análisis sociológico del cambio social y cultural en las sociedades contemporáneas. Madrid: Siglo.

Bajoit, Guy. 2009. Sócio-analyse des raisons d'agir: études sur liberte du sujet et l'acteur. Québec, Canadá: Les Press de l’Université Laval.

Bajoit, Guy. 2012. Vers une théorie socio-analytique de la relation sociale. Texto inédito cedido pelo autor.

Bajoit, Guy. (Fevereiro, 15, 2013). Email com carta pessoal em anexo.

Eiji, Hugo. 2012. O congresso de Milão. https://culturasurda.net/2012/08/18/teatr-deaf-poland/, https://culturasurda.net/congresso-de-milao/ acesso em 05/05/19, às 00h59

Fairclough, Norman. [2001] 2008. Discurso e mudança social. Brasília: Editora Universidade de Brasília.

Ghio, Elsa and María Delia Fernández. 2005. Manual de linguística sistémico funcional: el enfoque de M. A. K. Halliday \& R. Hasan - aplicaciones a la lengua española. Santa Fé Universidad Nacional del Litoral.

Gonçalves-Segundo, Paulo Roberto. 2018. “Discurso e prática social.” In Batista Jr, J. R. L.; Sato, D. T. B.; Melo, I. F De. (Org). Análise de discurso crítica para linguistas e não linguistas. São Paulo: Parábola.

Halliday, M. A. K. 2004. An introduction to Functional Grammar [Revisão de Christian M. 


\section{M. Matthiessen]. $3^{\text {a }}$ ed. London: Edward Arnold.}

Pedrosa, C. E. F. 2008. Análise de Discurso Crítica: do linguístico ao social no gênero midiático. Aracaju: EdUFS.

Pedrosa, C. E. F. 2016. "Análise crítica do discurso e a proposta da corrente nacional: da abordagem às primeiras pesquisas.” In Kallarrari, Celso; Bessa, Décio; Pereira, Aline Santos (comps.). Estudos linguísticos e formação docente. São Paulo: Pontes.

Pedrosa, C.E. F. 2018. “Análise Crítica do Discurso no PPGL: pesquisas ee contribuiçoes socais.” Pp 153-178 in Ramalho; Christina e Lima, Geralda. Estudos linguísticos e literários. Aracaju: Criação.

Magalhães, I; A. R. Martins and Vivien M. Resende. 2017. Análise de Discurso Crítica: um método de pesquisa qualitativa. Brasília: Editora da Universidade de Brasília,

Ricoeur, Paul. (04 de setembro de 2013). A identidade narrativa. Tradução comentada de Carlos João Correia. Disponivel em http://metafisica.no.sapo.pt/ricoeur.html.

Rocha, Solange. 2008. O INES e a educação de surdos no Brasil. Vol. 1, $2^{\mathrm{a}}$ ed (Dez $\left.\backslash 2008\right)$; Rio de Janeiro: INES.

Rochelle, E. L. 1880. Le Congrés de Milan pour l'amélioration du sort des sourds- muets; rapport adresse a M. Eugène Pereire. Paris: M. Saint-Jorre.

Sofiato, Cássia Geciauskas and Lucia Helena Reily. 2017. "A educação de surdos contada por meio de selos postais.” Revista Educação e Fronteiras On-Line, Dourados/ MS, v.7, n.19, p.6-18, jan./abr.

Strobel, Karin. 2009. História da Educação de Surdos. Florianópolis: UFSC.

Tomaszewski, P; Sak, M. 2014. „It os possible to educate deaf chidren billingally in Poland?” Pp. 129-149 in Zweisprachigket und billingualler unterricht, edited by M. Olpinska-Szielko and L. Bertelle. Peter Lang Presss.

Vieira, Josenia Antunes and Denise Silva Macedo. 2018. "Conceitos-Chave em Análise de Discurso Crítica." Pp. 48-77 in Análise de discurso crítica para linguistas e não linguistas. 1 ed, edited by J. R. L. Batista, D. T. B. Sato and I. F. De Melo. São Paulo: Parábola.

\section{BIOGRAPHICAL NOTE}

Cleide Emília Faye Pedrosa is senior researcher of Departament de Libras (Brazilian Sign Language) at the Federal University of Sergipe, Brazil.

OPEN ACCESS: This article is distributed under the terms of the Creative Commons Attribution Non-commercial License (CC BY-NC 4.0) which permits any non-commercial use, and reproduction in any medium, provided the original author(s) and source are credited. 
